\title{
Correspondence
}

Nordic principles in northern research: response to a review

Noel D. Broadbent

National Science Foundation, 1800 G Street, NW, Wash-

ington, DC 20550, USA

Received June 1991

Ian Whitaker's review (Polar Record 27(161): 142-43, 1991) of Readings in Saami history, culture and language and Nordic perspectives on Arctic cultural and political ecology expresses a point of view which demands comment. Although his treatment of both books is superficial, his comments on the second publication are particularly lacking in other, more serious, respects. Whitaker writes, 'My own personal view is that this second collection of papers is itself an excellent documentation of the impracticalities which many academics espouse'. This comment is made concerning, in part, a 'Nordic statement of principles and priorities in Arctic and northern research' published in this volume. One of its stated principles is that research proposals and results, 'as far as is feasible', should be translated into the languages of the people affected or dealt with by this research. Apparently, Dr Whitaker finds this concept unacceptable.

The Nordic principles statement emphasizes that 'the accountability of science and researchers to northern residents and their values, aspirations and integrity should be recognized'. These statements parallel documents formulated by the Association of Canadian Universities for Northern Studies (1982), the Inuit Circumnpolar Conference (1986) and, most recently, the United States Interagency Arctic Social Sciences Task Force. They are intended to promote understanding and cooperation between the research community and northern indigenous peoples. Dr Whitaker's exaggerated response to this attempt to address the lack of accountability that researchers have exhibited in the past is unworthy of contemporary anthropology and, as such, is the kind of arrogance that has given anthropology such a bad name among Native peoples like the Inuit, the Saami and the Greenlanders. Communicating research proposals and results to subjects is neither unrealistic nor impractical; in fact, not communicating this information is unethical. Without knowledge of relevant languages, or at least the use of interpreters, anthropology itself becomes impractical.

Dr Whitaker seems to view the authors of this book, and the statement of research principles, as the product of Ivory Tower academia. However, not only are these senior Nordic scholars with years of field experience, but many including Dr Elina Helander, Prof Robert Peterson, Prof Louise Backman, Pekka Aikio and Steinar Pedersen are also Native people.
While obtaining informed consent of research subjects and communicating results of research back to Native communities entails a number of problems which may seem 'impractical' to Ian Whitaker, without this accountability research on human subjects, or on the environments upon which they depend, cannot be endorsed. If anybody is in an Ivory Tower, it is Ian Whitaker!

[Editor's note: Dr Whitaker, who is currently on fieldwork, may reply in a later issue.]

\section{Lead poisoning and the Franklin expedition}

\section{Ann Shirley}

Little Bridge Place, Bridge, Canterbury, Kent CT4 5LG

Received November 1991

Derek Fordham's comment concerning unwarranted assumptions that lead poisoning caused the deaths of Sir John Franklin and his men (correspondence, Polar Record $163: 371,1991)$ has worried me in relation to the findings of Beattie and his colleagues (Beattie and others 1987, Frozen in time, London, Bloomsbury; Kowal and others, 1990, Did solder kill Franklin's men? Nalure 343: 319-20). Is it not worth noting that Lt Graham Gore's entry on the last Franklin record, dated 28 May 1847, includes the phrase 'All well'? This was two years after Erebus and Terror had left England. It was during the third year, 1847-48, that Franklin, nine officers and 15 men died, according to Capt F. R. M. Crozier's additional entry on the same record dated 25 April 1848.

The article 'Nutritional aspects of the British Arctic Expedition of 1875-76 and its predecessors' (Savours, A. and Deacon, M. In: Watt, J and others (editors). 1981, Starving sailors, London, National Maritime Museum: 131-62) includes photographs of tins from Sir John Franklin's expedition, now held in the National Maritime Museum and elsewhere, and one of a piece of tinned beef from a Franklin expedition tin brought back by McClintock in 1859. Opened in 1926, the meat was found to be 'perfectly satisfactory', and has since been on display in the museum's Arctic gallery. Written long before the exhumations on Beechey Island, the article draws attention to the booklet 'Historic tinned food' (International Tin Research and Development Council, 1939) and to the work of C. C. Lloyd and J. L. S. Coulter (1963, Medicine and the navy, vol. 4, Edinburgh, Livingstone). R. J. Cyriax (1939, The lost Franklin expedition, London, Bloch) concluded that scurvy was the main cause of the disaster. $K$. J. Carpenter (1986, The history of scurvy and vitamin C, Cambridge, Cambridge University Press) provides a more recent study of the disease. 